\title{
Front Matter: Volume 7123
}

, "Front Matter: Volume 7123," Proc. SPIE 7123, Remote Sensing of the Environment: 16th National Symposium on Remote Sensing of China, 712301 (24 November 2008); doi: 10.1117/12.822012

SPIE Event: Remote Sensing of the Environment: 16th National Symposium on SPIE. Remote Sensing of China, 2007, Beijing, China 


\title{
PROCEEDINGS OF SPIE
}

\section{Remote Sensing of the Environment: 16th National Symposium on Remote Sensing of China}

\author{
Qingxi Tong \\ Editor
}

\section{7-10 September 2007 Beijing, China}

\section{Organized by}

China Land Resources Aero-geophysical Centre for Remote Sensing • China Land Surveying and Planning Beijing Municipal Bureau of Land and Resources • Twenty-First Aerospace Technology Company, Ltd.

Sponsored by

Committee of Remote Sensing for Geology, The Geological Society of China • Association on Environment Remote Sensing of China • Committee on Ocean Remote Sensing, Chinese Society of Oceanography • Committee on Satellite Meteorology and Space Weather, China Meteorological Society • Committee on Space Remote Sensing, Chinese Society of Space Research - Committee on Photogrammetry and Remote Sensing, Chinese Society of Geodesy, Photogrammetry, and Cartography • Committee on Space Remote Sensing, Chinese Society of Aeronautics and Astronautics • Technical Committee on Avionics, Chinese Society of Aeronautics • Committee on Telemetry, Remote Sensing, and Control, Chinese Association of Automation • Committee on Software Industry, China Association for Geographic Information System • Committee on Remote Sensing, Chinese Society for Optical Science Committee on Remote Sensing, Chinese Hydraulic Engineering Society • Affiliated Society of Land Information and Remote Sensing, Chinese Land Society • Committee on Remote Sensing for Land and Resources, Chinese Association of Remote Sensing Applications • National Remote Sensing Center of China $\bullet$ CNCRS-Chinese National Committee for Remote Sensing

Cooperating Organization and Publisher SPIE

Volume 7123 
The papers included in this volume were part of the technical conference cited on the cover and title page. Papers were selected and subject to review by the editors and conference program committee. Some conference presentations may not be available for publication. The papers published in these proceedings reflect the work and thoughts of the authors and are published herein as submitted. The publisher is not responsible for the validity of the information or for any outcomes resulting from reliance thereon.

Please use the following format to cite material from this book:

Author(s), "Title of Paper," in Remote Sensing of the Environment: 16th National Symposium on Remote Sensing of China, edited by Qingxi Tong, Proceedings of SPIE Vol. 7123 (SPIE, Bellingham, WA, 2008) Article CID Number.

ISSN 0277-786X

ISBN 9780819473578

Published by

SPIE

P.O. Box 10, Bellingham, Washington 98227-0010 USA

Telephone +1 3606763290 (Pacific Time) · Fax +1 3606471445

SPIE.org

Copyright (c) 2008, Society of Photo-Optical Instrumentation Engineers

Copying of material in this book for internal or personal use, or for the internal or personal use of specific clients, beyond the fair use provisions granted by the U.S. Copyright Law is authorized by SPIE subject to payment of copying fees. The Transactional Reporting Service base fee for this volume is $\$ 18.00$ per article (or portion thereof), which should be paid directly to the Copyright Clearance Center (CCC), 222 Rosewood Drive, Danvers, MA 01923. Payment may also be made electronically through CCC Online at copyright.com. Other copying for republication, resale, advertising or promotion, or any form of systematic or multiple reproduction of any material in this book is prohibited except with permission in writing from the publisher. The CCC fee code is 0277-786X/08/\$18.00.

Printed in the United States of America.

Publication of record for individual papers is online in the SPIE Digital Library.

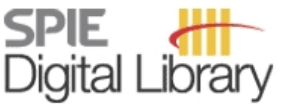

SPIEDigitalLibrary.org

Paper Numbering: Proceedings of SPIE follow an e-First publication model, with papers published first online and then in print and on CD-ROM. Papers are published as they are submitted and meet publication criteria. A unique, consistent, permanent citation identifier (CID) number is assigned to each article at the time of the first publication. Utilization of CIDs allows articles to be fully citable as soon they are published online, and connects the same identifier to all online, print, and electronic versions of the publication. SPIE uses a six-digit CID article numbering system in which:

- The first four digits correspond to the SPIE volume number.

- The last two digits indicate publication order within the volume using a Base 36 numbering system employing both numerals and letters. These two-number sets start with 00, 01, 02, 03, 04 , 05, 06, 07, 08, 09, OA, OB ... 0Z, followed by 10-1Z, 20-2Z, etc.

The CID number appears on each page of the manuscript. The complete citation is used on the first page, and an abbreviated version on subsequent pages. Numbers in the index correspond to the last two digits of the six-digit CID number. 


\section{Contents}

ix Editorial Committees

xi Introduction

\section{SESSION 1 TECHNOLOGY AND METHODOLOGY}

712302 Calibration precision analysis for spaceborne microwave radiometer [7123-01]

L. Peng, J. Zhao, Graduate Univ. of Chinese Academy of Sciences (China) and Ctr. for Space Science and Applied Research (China); D. Zhang, Ctr. for Space Science and Applied Research (China)

712303 Experiment study on quantitative retrieval of mineral abundances from reflectance spectra [7123-02]

B. Yan, S. Liu, R. Wang, X. Guo, China Aero Geophysical Survey and Remote Sensing Ctr. for Land and Resources (China); W. Sun, Xinjiang Bureau of Exploration and Development of Geology and Mineral Resources (China)

\section{SESSION 2 ALGORITHMS AND MODELS}

712304 Quality improvement of Beijing-1 small satellite images [7123-03]

Q. Ran, Y. Chi, Institute of Remote Sensing Applications (China) and Beijing Landview Mapping Information Technology Co., Ltd. (China); Z. Wang, Beijing Landview Mapping Information Technology Co., Ltd. (China)

712305 The imaging method and sampling scheme of rotation scanning interferometric radiometer [7123-04]

C. Zhang, J. Wu, Ctr. for Space Science and Applied Research (China); W. Sun, Ctr. for Space Science and Applied Research (China) and Univ. of Science and Technology of China (China)

712306 Atmospheric correction of hyperspectral data using MODTRAN model [7123-05] Y. XU, China Univ. of Geosciences (China); R. Wang, S. Liu, S. Yang, B. Yan, China Aero Geophysical Survey and Remote Sensing Ctr. for Land and Resources (China)

712307 Study and improvement on a retrieval algorithm of aerosol optical depth over ocean [7123-06]

W. Li, S. Mao, Beijing Univ. of Aeronautics and Astronautics (China); J. Huang, Nanjing Univ. of Science and Technology (China)

712308 Accuracy analysis of remote sensing image rectification [7123-07] W. Jiao, B. Cheng, W. Zhu, W. Liu, G. He, W. Wang, X. Zhang, Ctr. for Earth Observation and Digital Earth (China)

712309 An improved algorithm of hyperspectral image endmember extraction using projection pursuit [7123-08]

Z. Yang, H. Zhao, Beihang Univ. (China) 
$7123 \mathrm{OA}$ Modeling simulation and inversion for microwave active and passive remote sensing of the lunar surface [7123-09]

Y.-Q. Jin, W. Fa, F. Xu, Fudan Univ. (China)

\section{SESSION $3 \quad$ IMAGE PROCESSING}

$7123 \mathrm{OB} \quad$ Study on Spot5 remote sensing imagery automatic registration methods based on texture feature points [7123-10]

C. Chu, Ctr. for Earth Observation and Digital Earth (China); D. Yan, Ctr. for Earth Observation and Digital Earth (China) and Institute of Automation (China); C. Wang,

H. Zhang, Ctr. for Earth Observation and Digital Earth (China)

7123 OC Multi-scale wavelet super-resolution image reconstruction based on nonuniform sampling multi-frame images [7123-11]

J. Wang, Y. Zhao, Q. Gao, Beijing Remote Sensing Information Research Institute (China)

7123 OD An improved algorithm for shadow restoration of high spatial resolution imagery [7123-12] Q. J. Wang, Ctr. for Earth Observation and Digital Earth (China); Q. J. Tian, Nanjing Univ. (China); Q. Z. Lin, Ctr. for Earth Observation and Digital Earth (China); M. X. Li, China Earthquake Networks Ctr. (China); L. M. Wang, Ctr. for Earth Observation and Digital Earth (China)

\section{SESSION 4 ATMOSPHERE}

$7123 \mathrm{OE} \quad$ Analysis of trends of urban heat island and its drivers in Chengdu [7123-13] S. Dan, Sichuan Academy of Environmental Sciences (China) and Sichuan Meterological Bureau (China); B. Dan, Sichuan Provincial Meteorological Observatory (China); J. Liao, Sichuan Academy of Environmental Sciences (China); J. Xia, Chengdu Univ. of Information Technology (China); G. Chen, Sichuan Provincial Meteorological Observatory (China); H. Xu, Chengdu Univ. of Technology (China); Q. Ye, Sichuan Academy of Environmental Sciences (China)

7123 OF Application of AOT products derived from ASTER data to the air pollution research around the Beijing Olympic Games area [7123-14]

J. Guang, Institute of Remote Sensing Applications (China), Beijing Normal Univ. (China), and Graduate School of the Chinese Academy of Sciences (China); Y. Xue, Institute of Remote Sensing Applications (China), Beijing Normal Univ. (China), and London Metropolitan Univ. (United Kingdom); L. Bai, Institute of Remote Sensing Applications (China), Beijing Normal Univ. (China), and Graduate School of the Chinese Academy of Sciences (China); J. Guo, Ctr. for Atmosphere Watch and Services (China)

7123 OG Analysis on seasonal characteristics of UHI in Beijing city using Landsat 5 TM data [7123-15] Z. Zhang, Institute of Remote Sensing Applications (China), Ctr. for Earth Observation and Digital Earth (China), and Graduate School of the Chinese Academy of Sciences (China); G. He, Ctr. for Earth Observation and Digital Earth (China) 
$7123 \mathrm{OH} \quad$ Research on the meso-scale convective systems based on remote sensing images from multisources [7123-16]

J. Bai, J.-W. Liu, Beijing Aviation Meteorology Institute (China); B.-Q. Zhu, Ctr. for Earth

Observation and Digital Earth (China); X.-W. Wang, Beijing Aviation Meteorology Institute

(China)

\section{SESSION 5 GEOLOGY AND MINERALS}

$7123 \mathrm{OI} \quad$ SAR and multi-spectral images fusion for shallow-buried fracture detection in urban area [7123-17]

L. Yu, D. Zhang, W. Zhang, Q. Huang, Zhejiang Univ. (China)

$71230 \mathrm{~J}$ The strike and pattern of the Bam blind fault inferred from synthetic aperature radar data [7123-18]

X. Zha, R. Fu, Z. Dai, B. Liu, Y. Chen, T. Xue, Univ. of Science and Technology of China (China)

7123 OK The information of oil and gas micro-seepage in Dongsheng region of inner Mongolia based on the airborne hyperspectral remote sensing image [7123-19]

S.-F. Tian, J.-P. Chen, M. Zhou, China Univ. of Geosciences (China)

SESSION 6 LAND USE

$7123 \mathrm{OL} \quad$ Research on land use/cover change of opencast coal mining area of Pingshuo Shanxi [7123-20]

W. Zhou, Z. Bai, China Univ. of Geosciences (China); Z. Li, China Aero Geophysical Survey and Remote Sensing Ctr. for Land and Resources (China); Y. Wu, T. Yuan, M. Qian, China Univ. of Geosciences (China)

$71230 \mathrm{M}$ Extraction and monitoring of Karst rock desertification information [7123-21]

Z. Li, China Aero Geophysical Survey and Remote Sensing Ctr. for Land and Resources (China); S. Kuang, C. Dai, Guizhou Academy of Geological Survey (China); C. Wang, Institute of Remote Sensing Applications (China)

$71230 \mathrm{~N}$ Study on the automatic classification for land use/land cover in arid area based upon remotely sensed image cognition [7123-22]

A. Li, Y. Liu, Y. Guo, H. Wang, Lanzhou Univ. (China)

$712300 \quad$ The main evolution of remote sensing for land resources of China in recent years [7123-23] P. Wang, China Aero Geophysical Survey and Remote Sensing Ctr. for Land and Resources (China); J. Ju, Ministry of Land and Natural Resources (China); Z. Li, Y. Wang, China Aero Geophysical Survey and Remote Sensing Ctr. for Land and Resources (China); D. Zhang, Zhejiang Univ. (China); Z. Zhang, China Univ. of Geosciences (China); X. Chen, Peking Univ. (China); J. Zhao, Chinese Academy of Surveying and Mapping (China)

7123 OP Research on the remote sensing application system of national land supervision [7123-24] L. Wen, China Land Surveying and Planning Institute (China) and Shenyang Agriculture Univ. (China); Y. Chai, W. Li, L. X. Zhou, China Land Surveying and Planning Institute (China) 
$71230 Q \quad$ System research and demonstrating application of Double Star combined new mode of survey on the situation of land use [7123-25]

Y. Wang, Beijing Municipal Bureau of State Land and Resources (China); Z. Ji, Y. Chen, J. Gu, Twenty First Century Aerospace Technology Co., Ltd. (China); X. Wu, W. Yin, Southeast Univ. (China)

7123 OR Abstracting of suspected illegal land use in urban areas using case-based classification of remote sensing images [7123-26]

F. Chen, Graduate Univ. of Chinese Academy of Sciences (China) and Ctr. for Earth Observation and Digital Earth (China); C. Wang, Ctr. for Earth Observation and Digital Earth (China); C. Yang, Shenzhen Municipal Administration of Land, Resources, and Real Estate (China); H. Zhang, F. Wu, Ctr. for Earth Observation and Digital Earth (China); W. Lin, Shenzhen Municipal Administration of Land, Resources, and Real Estate (China); B. Zhang, Ctr. for Earth Observation and Digital Earth (China)

\section{SESSION 7 ECOLOGY AND ENVIRONMENT}

7123 OS Dynamic changes of lakes and the geo-mechanism in Tibet based on RS and GIS technology [7123-27]

Q. Jiang, Jilin Univ. (China); H. Fang, China Aero Geophysical Survey and Remote Sensing Ctr. for Land and Resources (China); Y. Li, J. Zhang, Jilin Univ. (China)

7123 ОT Remote sensing survey of surface water environment in urban areas: cases in Beijing, Kunming, and Wuhan [7123-28]

R. Zhang, S. Tian, China Univ. of Geosciences (China)

7123 OU Water color component analysis in saltwater intrusion reach: a case study in ShawanHumen Watercourse, Pearl River Estuary [7123-29]

L. Fang, Suzhou Vocational Univ. (China) and Guangzhou Institute of Geography (China);

S. Chen, Guangzhou Institute of Geography (China), Beijing Normal Univ. (China), Institute of Remote Sensing Applications (China), and South China Agriculture Univ. (China); D. Li, Guangzhou Institute of Geography (China); L. Zhang, Beijing Normal Univ. (China) and Institute of Remote Sensing Applications (China); D. Li, Water Supply Corp. of Panyu District (China)

7123 OV Water quality monitoring by remote sensing in Hushan Tailings Reservoir of Huji, Hubei Province [7123-30]

Q. Yang, Z. Zhang, W. Chen, China Univ. of Geosciences (China); L. Qian, Huangshan Univ. (China)

7123 oW A general method of spatial scaling for leaf area index [7123-31]

T. Li, Ctr. for Earth Observation and Digital Earth (China); H. Wu, Institute of Geographical Sciences and Natural Resources Research (China) and Graduate Univ. of Chinese Academy of Sciences (China); B. Zhu, L. Ni, Ctr. for Earth Observation and Digital Earth (China)

$71230 X$ Retrieval of reed biomass based on multi-time remote sensing data: a case study on ShuangTai Estuary Nature Reserve, Panjin [7123-32]

A. Chen, Fujian Normal Univ. (China); Y. Wan, China Univ. of Petroleum (China); J. Zhang, Y. Wu, Ctr. for Earth Observation and Digital Earth (China) 
7123 OY Retrieval of cyanobacteria in Taihu based on MODIS data [7123-33]

X. Han, National Satellite Meteorological Ctr. (China); P. Cong, National Marine Environment Monitoring Ctr. (China); Y. Qin, Institute of Remote Sensing Applications (China); X. Zhu, National Satellite Meteorological Ctr. (China)

$71230 Z$ Application of knowledge-based decision tree classification method to monitoring ecological environment in mining areas based on the multi-temporal Landsat TM(ETM) images: a case study at Daye, Hubei, China [7123-34]

S. Yu, China National Petroleum Corp. (China)

712310 A preliminary approach on the synchronically ground based measurement of spectral reflectance, NDVI, LAI, and the temperature and moisture of soils [7123-35]

Y. Liu, Y. Guo, J. Wang, J. Fan, X. Wang, Y. Nian, Lanzhou Univ. (China)

$712311 \quad$ Remote sensing of marine oil spills and its applications [7123-36]

Y. Li, L. Ma, S. YU, C. Li, Q. Li, Dalian Maritime Univ. (China)

712312 Analysis of water spectral features of petroleum pollution and estimate models from remote sensing data [7123-37]

M. Huang, Dalian Fisheries Univ. (China); W. Yu, Y. Zhang, J. Shen, X. Qi, PetroChina Co., Ltd. (China)

712313 Detection and evaluation on phosphorite mining environment contamination sources using ASTER and DEM [7123-38]

W. Chen, Z. Zhang, China Univ. of Geosciences (China); Z. Li, China Aero Geophysical Survey and Remote Sensing Ctr. for Land and Resources (China); J. Yang, L. Qian, China Univ. of Geosciences (China)

\section{SESSION 8 DISASTER MONITORING}

712314 Study in landslide hazard zonation based on factor weighting-rating in Wan County, Three Gorges Reservoir area [7123-39]

Z. Liu, Chinese Academy of Surveying and Mapping (China); J. Wang, Chinese Academy of Surveying and Mapping (China) and Chinese Univ. of Mining Technology (China); C. Chi, Chinese Academy of Surveying and Mapping (China) and Shandong Univ. of Science and Technology (China)

712315 The study in deformation and destruction mechanism of Qianjiangping landslide in Three Gorges Reservoir area [7123-40]

R. Yang, Z. Wang, J. Yang, China Aero Geophysical Survey and Remote Sensing Ctr. for Land and Resources (China); Z. Wang, China Water Resources Beifang Investigation Design and Research Co., Ltd. (China)

712316 Distribution of forest fire prevention resources based on GIS [7123-41]

A. XU, L. Tang, Zhejiang Forestry Univ. (China); Z. Chen, X. Zhang, Institute of Remote Sensing Applications (China)

712317 Forecasting method of national-level forest fire risk rating [7123-42]

X. Qin, Research Institute of Forest Resource Information Technology (China); Z. Zhang, State Forestry Administration (China); Z. Li, H. Yi, Research Institute of Forest Resource Information Technology (China) 
712318 Method for extraction of quantitative information using remote sensing data of underground coal fire areas and its application [7123-43]

F. Dang, Z. Li, S. Xiong, H. Fang, R. Yang, China Aero Geophysical Survey and Remote Sensing Ctr. for Land and Resources (China)

Author Index 


\title{
Editorial Committees
}

\author{
Editors-in-Chief \\ Qingxi Tong (Academician) \\ Jiang Min (Vice-Minister of the Ministry of Land and Resources, \\ Director of China Geological Survey)
}

\section{Associate Editors-in-Chief}

Xianlin Liu (Academician), Huixing Gong (Academician),

Jingshan Jiang (Academician), Yongqi Xue (Academician),

Ping Wang

\section{Contributing Editors}

Guanghua Wang, Yirong Wu, Shuang Wu, Chuanrong Li,

Wenjiang Zhang, Guocheng Zhang, Jun Yang, Fangneng Zheng,

Lizhong Zheng, Yiming Jin, Chenghu Zhou, Huili Gong, Huadong Guo,

Xiaozhe Qiang, Wei Gao, Qiming Qin, Huajun Tang, Xingfa Gu,

Yingnan Liang, Qiming Peng, Junqi Xie, Xiaohan Liao,

Shengqing Xiong, Jianhua Ju, Wuyi Yu, Youchuan Wan, Hongbin Fang,

Naimeng Lu, Heguang Liu, Boqin Zhu, Xiuwan Chen, Kaitao He,

Feng Lu, Bing Zhang, Zhi Zhang, Dengrong Zhang, Yaowu Chi,

Jiahong Li, Jiren Li, Zhizhong Li, Jing Li, Zengyuan Li, Minsen Lin,

Qigang Jiang, Zhongming Zhao, Jicheng Zhao, Huijie Zhao, Suning Xu,

Ping Gao, Chun Yuan, Yuan Chai, Wei Cao, Jinshan Mei, Yan Wang,

Erhe Wang, Yupu Wang, Zhiyong Wang, Jianzhong Sun, Andong Liu, Liangming Liu, Kaitao He, Youyan Zhang, Rihong Yang, Wunian Yang, Ruiyun Zhao, Dong Jiang, Xuwen Qin, Li Wen, Guifei Jing, Shuying Cai 
Downloaded From: https://www.spiedigitallibrary.org/conference-proceedings-of-spie on 26 Apr 2023

Terms of Use: https://www.spiedigitallibrary.org/terms-of-use 


\section{Introduction}

The National Symposium on Remote Sensing Technologies is traditionally held every two years. Since the closing of the 16th National Symposium on Remote Sensing Technologies in 2007, and during the compilation of those proceedings, China has suffered numerous and extremely serious natural disasters. Unseasonably low temperatures, heavy rain, and snow/ice disasters occurred during a one month time period in the spring of 2008 within the largest areas of southern China. Immediately following, on 12 May 2008, a tremendously destructive earthquake, measuring at a magnitude of 8.0 on the Richter scale, hit the Sichuan Province. More than 80,000 people were killed as a result of this terrible disaster. Never before in southern China's history has so much devastation occurred over such a short period of time.

Recognizing their responsibilities to those who have been impacted by these disasters, the Chinese community of remote sensing scientists and technicians has devoted themselves to assisting those who are struggling to cope with the impact this tragedy has made on their lives. As a result, the compilation and publishing of these proceedings has unfortunately, to some extent, taken longer to finalize than expected.

This proceedings volume is comprised of papers that have been selected from those presented at the aforementioned 16th National Symposium on Remote Sensing Technologies, held in Beijing on 8-12 September 2007, and the Conference on Remote Sensing of the Environment, held in Dalian 15-18 August 2008. The academic exchanges and discussions at both the symposium and the conference promoted the understanding and development of remote sensing science, technology, and their applications. The integration and combination of remote sensing, GIS, and satellite positioning techniques were also promoted. All papers presented in these sessions were selected and carefully reviewed by a scientific committee organized for the purpose of editing these proceedings, resulting in a total of 43 published papers.

China's remote sensing community has continually progressed over recent years. To a certain extent, the papers presented in these proceedings are a representation of this progress. They cover such major areas of remote sensing as fundamental research, technical development, resource and environmental management, and disaster monitoring. The method of atmospheric correction for hyperspectral data was studied in the areas of fundamental research and technical development. The study on the modeling and inversion for microwave remote sensing was also conducted. The significance of the application of these methods is a direct result of China's first lunar exploration project. 
In the hyperspectral domain, the study on quantitative retrieval of mineral abundance based on spectral unmixing and endmember extraction has been carried out. The study of calibration of spaceborne microwave radiometers and a new image method and sampling scheme has been proposed for the development of a microwave sensoring system. The studies on quality improvement, including noise removal and image restoration of small satellites, super-resolution image reconstruction, and the shadow elimination for high resolution images were useful in the application of satellite remotely sensed data.

By using the short revisiting characteristics of the Beijing-1 small satellite, techniques that integrate remote sensing images with GPS-based positioning and mapping devices were developed for land surveys so that the regional land use survey and the dynamical analysis could be performed quarterly, or even monthly. The majority of the papers focused on the studies of multidisciplinary applications, including land resources protection, and the environmental and disaster monitoring that was conducted. Some studies also focused on surface water environment and heat island effect in urban areas. The quality of inland, estuary, and offshore water, including chlorophyll, chromophoric dissolved organic matter, spatial distribution, and marine oil spills were studied as well. Special attention was paid to disaster management, such as the forecasting method of forest fire risk rating, detection of the buried fracture in urban areas, and monitoring landslides.

I would like to take this opportunity to express my sincere thanks to the Committee of Remote Sensing for Geology, the Geological Society of China, the Committee on the Environment of Remote Sensing, and the Chinese Society of Geography for their significant contributions in hosting and organizing the very successful aforementioned symposium and conference. Special thanks are also expressed to Dr. Wei Gao, the Chairman of the Remote Sensing Program of SPIE, and Director of the USDA UV-B Monitoring and Research Program and Professor in Department of Soil and Crop Sciences at Colorado State University, Fort Collins, for his support and direction of the meeting and the proceedings. Our sincere thanks also go to the Chinese National Committee for Remote Sensing in addition to other numerous cooperating sponsors, the cooperating and supporting society, associations, organizations, and agencies for their contributions to the success of these events.

In conclusion, it is my great honor to present these proceedings in their final publication.

Qingxi Tong

CNCRS - Chinese National Committee for Remote Sensing Institute of Remote Sensing Applications, Chinese Academy of Sciences 